\title{
The influence of mixing inside the fermentation reactors during the study of biogas efficiency of the substrates in mesophilic technology
}

\author{
Kamil Kozlowski ${ }^{1, *}$, Marta Cieslik $^{2}$, JakubMazurkiewicz ${ }^{1}$, Anna Smurzynska ${ }^{1}$, Michal Brzoski ${ }^{1}$, Dawid \\ Chelkowski $^{1}$, Aleksandra Jezowska ${ }^{1}$, Maciej Neugebauer $^{3}$, Tomasz Oniszczuk ${ }^{4}$, Karol Kupryaniuk $^{4}$ \\ ${ }^{1}$ Poznan University of Life Sciences, Institute of Biosystems Enginering, Wojska Polskiego 50, 60-637 Poznan, Poland \\ ${ }^{2}$ Poznan University of Life Sciences, Department of Biotechnology and Food Microbiology, Wojska Polskiego 48, 60-637 \\ Poznan, Poland \\ ${ }^{3}$ Faculty of Technical Sciences University of Warmia and Mazury in Olsztyn, Department of the Electrotechnic Energetics \\ Electronics and Automatics, Oczapowskiego 11, 10-719 Olsztyn, Poland \\ ${ }^{4}$ Lublin University of Life Sciences, Department of Process Engineering, Gleboka 28, 20-612 Lublin, Poland
}

\begin{abstract}
Along with the development of environmental friendly technologies, an increasing interest in generating the electricity and heat from renewable sources has been observed in Poland. Perfect example of such installations are agricultural biogas plants, where methane fermentation produces high-energy gas fuel i.e. biogas. Before investing, it is necessary to perform a detailed studies of the biogas efficiency of the substrates used. The proper run of fermentation process, as well as the high biogas production related to the operation, depend on many factors, including the mixing inside the reactor. The DIN 38 414-S8 standard, commonly used in the tests, assumes the mixing of the whole eudiometric sets, used in accredited laboratory units, which due to their uniform construction may cause problems. The aim of the study was to determine the effect of laboratory mixing in the fermentation reactor on the biogas efficiency of the maize straw. The experiment tests were performed in the Laboratory of Ecotechnologies, in the Poznan, in accordance with the current standard DIN 38 414-S8. The obtained research results confirmed the effect of mixing inside the fermentation reactors on the biogas efficiency of the maize straw.
\end{abstract}

\section{Introduction}

Constant increase in demand for electricity, heat and fossil fuels results primarily from intensive development of civilization in the last century and the observed increase in the population of the world. These factors also cause a noticeable increase in environment pollution [1]. Bearing in mind these unfavourable changes, the use of new technologies for the production of environmentally friendly energy becomes more important $[2,3]$. During the ongoing energy crisis, the use of alternative energy sources such as hydrogen or methane seems to be the most advantageous solution [4, 5].

Currently, it is believed that the most significant contribution to the production of unconventional fuels is likely to be substrates with relatively low purchase costs, which are waste from agriculture and the agro-food industry [6-8]. These materials can be easily used in composting and methane fermentation $[2,9,10]$ and methane fermentation [11]. It should be noted that Poland is a country with a high potential for energy from agricultural biogas $[7,12]$. Unfortunately, this potential is not fully exploited. According to the register of producers of agricultural biogas, as of 25.07.2017, there are 95 agricultural biogas plants in Poland [13]. However, anticipate that with the development of renewable energy sources new installations will be developed and produced using agricultural biogas [14].

Biogas is included in the group of renewable energy sources [15]. For many years, intensive methane fermentation and the use of biomass and its decomposition products in the industry have been carried out worldwide $[1,8,16,17,19,20]$. The efficiency of the fermentation process depends on many process factors such as temperature [16], $\mathrm{pH}$ [20], $\mathrm{C} / \mathrm{N}$ ratio [21, 22], hydraulic retention time (HRT) [21] and reactor organic load rate (OLR) [23].

However, one of the equally important factors affecting the final yield of biogas is the mixing of the contents of the fermentation reactors [24, 25]. DIN 38 414-S8 standard is commonly used for the biogas substrate tests [26-28]. This standard takes into account the mixing of the eugenic sets by careful movement of the circular motions [29, 37]. These sets are used by many accredited laboratory units. Unfortunately, due to the uniform construction, mixing of their contents can be

*Corresponding author: kamil.kozlowski@up.poznan.pl 
difficult, which can significantly affect the final result of the biogas and methane yields.

A possible solution is to use sets equipped with a mechanical mixing system or reactors to allow accurate manual mixing, with an independent gas storage system. The first solution is mainly used in fermentation stations used in continuous process studies [24, 30, 36]. An additional problem may be the gas seal introduced into the inside of the mixer, which prevents oxygen from entering the reactor. In this case, it is important to use fermentation kits equipped with an independent gas storage system and the possibility of free manual mixing of the contents take place. Such stations were constructed in the Department of Environmental Engineering at the Institute of Biosystems Engineering at Poznan University of Life Sciences (Figure 1).

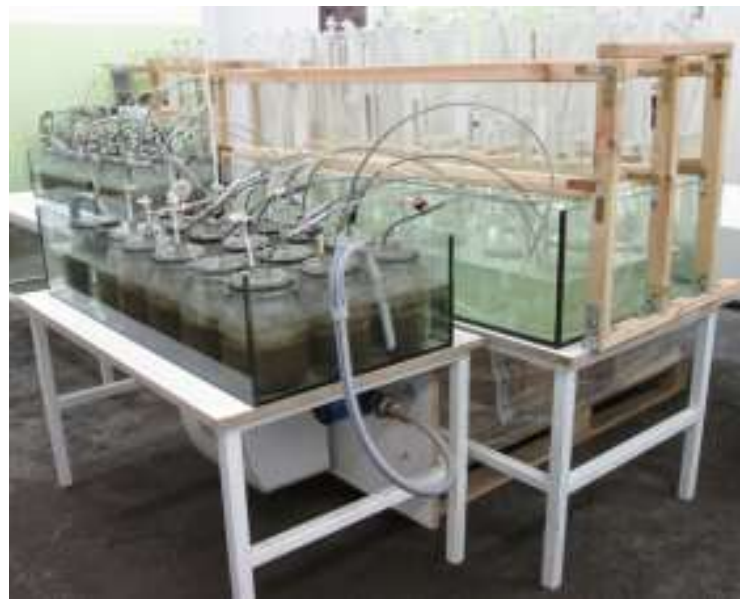

Fig. 1.The biofermenter for biogas production research in Laboratory of Ecotechnology at Poznan University of Life Sciences.

The aim of the study was to determine the effect of laboratory mixing in the fermentation reactor on the biogas efficiency of the maize straw.

\section{Materials and methodology}

\subsection{Analysis of basic parameters}

The analyses of basic physicochemical parameters of the substrates and inoculum were conducted according to Polish standards: dry matter (PN-75 C-04616/01), dry organic matter (PN-Z-15011-3) and $\mathrm{pH}$ (PN 90 C$04540 / 01)$. These parameters enabled the selection of appropriate proportions of fermentation mixtures and subsequent calculation of the biogas efficiency calculated on $\mathrm{Mg}$ of fresh matter, dry matter and dry organic matter of the substrate.

\subsection{Biogas efficiency}

The research tests on methane efficiency of the substrates in batch culture technology were carried out in the Laboratory of Ecotechnologies at the Institute of Biosystems Engineering at the Poznan University of Life Sciences on basis of internal procedures, based on adapted standards: DIN 38 414-S8 and VDI 4630, commonly used in Europe. Detailed methodology of performed research was presented by Cieslik et al. [26]. The tested material was maize straw, which obtained from Przybroda Agricultural-Orchard Experimental Farm belonging to the Poznan University of Life Sciences (PULS). The fermentative inoculum was separated liquid fraction (after dry mass separator) taken from operating agricultural biogas plant in Dzialyn (Poland). After sampling from dig estate tank, Inoculum was storing in anaerobic conditions in room temperature.

To determine the effect of stirring of fermentation reactors on the biogas yield of corn straw, the individual reactors were subjected to circular stirring at different intervals: daily, twice a week (Monday and Thursday) and without mixing throughout the experiment.

\section{Result and discussion}

\subsection{Physical and chemical parameters}

In the first stage of the experiment, basic physicochemical parameters of the substrate and two grains were analysed, the results of which are presented in Table 1. These parameters were necessary to determine the appropriate fermentation mixtures and subsequent calculations of the biogas yield

Table 1. Physical and chemical parameters of maize straw and inoculum.

\begin{tabular}{|c|c|c|c|c|}
\hline 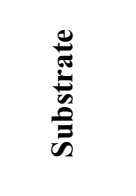 & 플 & 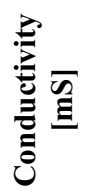 & 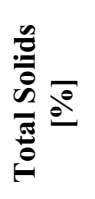 & 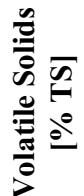 \\
\hline $\begin{array}{l}\text { Maize } \\
\text { straw }\end{array}$ & 9.66 & 1.41 & 77.80 & 89.78 \\
\hline Incoulum & 7.87 & 13.10 & 2.91 & 70.04 \\
\hline
\end{tabular}

The incubation used in the experiment was characterized by organic matter in fresh weight of about $2.1 \%$. The total solids and volatile total solids content of maize straw used in the experiment were $77.80 \% \mathrm{FM}$ and $89.78 \%$ TS, respectively.

\subsection{Daily dynamic of methane production}

Figure 2 shows the dynamics of methane production in fermentation reactors. During the process, differences in the dynamics of gas production were observed, which were influenced by the mixing frequency of the reactors. 


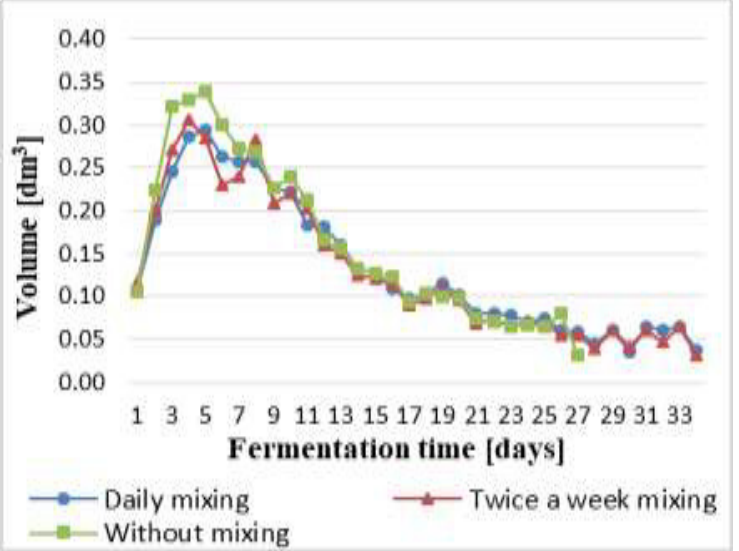

Fig. 2. Daily dynamic of methane production from reactors.

During the mesophilic fermentation, two distinct gas production peaks were observed. They were recorded on the 3rd and 8th day of the trial. The local peaks of biogas production are primarily due to the complex construction of the test material, since the simple sugars are converted to biogas faster than proteins or fat [26]. What is worth noting is the intensity of production peaks of gas in reactors that was mixed twice a week. This means that mixing of the fermentation reactor affects the change in the daily dynamics of gas production. In addition, shortening the total digestion time of the substrate in the case of daily mixing of the contents of the reactor was observed. This phenomenon may be due to the accurate distribution of fermentation microbes throughout the volume of the liquid, and consequently the potential for the formation of bacterial consortia.

\subsection{Biogas and methane efficiency of the substrate}

The following table 2. shows the biogas yield and methane concentration in biogas from the tested methane fermented substrates under mesophilic conditions.

Table 2. The biogas and methane efficiency.

\begin{tabular}{|c|c|c|c|c|c|}
\hline \multirow[b]{2}{*}{ 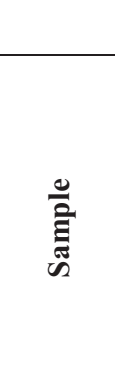 } & \multirow[b]{2}{*}{ 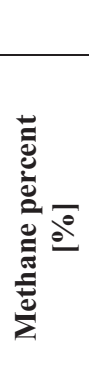 } & \multicolumn{2}{|c|}{ Fresh matter } & \multicolumn{2}{|c|}{ Volatile Solids } \\
\hline & & 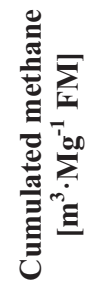 & 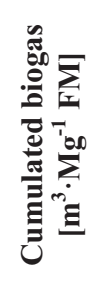 & 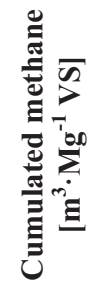 & 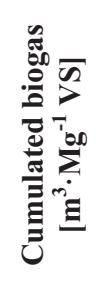 \\
\hline $\begin{array}{c}\text { Daily } \\
\text { mixing }\end{array}$ & 50.94 & 207.75 & 407.81 & 297.43 & 583.85 \\
\hline $\begin{array}{c}\text { Twice a } \\
\text { week } \\
\text { mixing }\end{array}$ & 50.24 & 196.50 & 391.10 & 281.33 & 559.93 \\
\hline $\begin{array}{l}\text { Without } \\
\text { mixing }\end{array}$ & 50.05 & 186.26 & 372.17 & 266.66 & 532.83 \\
\hline
\end{tabular}

In process of mesophilic fermentation of maize straw mixed every day, (as converted to $\mathrm{Mg}$ of fresh mass of substrate) $407.81 \mathrm{~m}^{3}$ of biogas with average methane content of 50.94\% was produced (table 2). However, in the case of corn straw mixed twice a week and without mixing, the yields of biogas and methane production were significantly lower by $16.71 \mathrm{~m}^{3} \cdot \mathrm{Mg}^{-1} \mathrm{FM}$ and $11.24 \mathrm{~m}^{3} \cdot \mathrm{Mg}^{-1} \mathrm{FM}$ and $35.64 \mathrm{~m}^{3} \cdot \mathrm{Mg}^{-1} \mathrm{FM}$ and 21.49 $\mathrm{m}^{3} \cdot \mathrm{Mg}^{-1}$ FM respectively.

The results of the studies made so far confirmed that the mixing of the fermented tank influences the efficient production of biogas [31-34]. In the absence of mixing the fermentation substance, the formation of layers on the surface of the fermentation mixture can be observed. Mass containing methanogenic bacteria is deposited in the lower part of the tank due to higher density. On the other hand, the decayed substrate collects in its upper layer. [35]. However, it should be borne in mind that excessive mixing of the contents of the fermentation reactor can also adversely affect microorganisms [24, $30]$.

\section{Conclusions}

1. The studies have confirmed the effect of mixing in the fermentation reactor to increase the production of biogas and biomethane.

2. Mixing in the fermentation reactor contributes to shortening the digestion time of the substrate.

3. Lower biogas yields due to lack of mixing of reactors during testing may have a significant impact on the estimation of the economic viability of the planned industrial scale investment.

\section{References}

1. R. Chandra, H. Takeuchi, T. Hasegaw, Renewable and Sustainable Energy Reviews, 16, 3, 1462-1476 (2012), DOI: 10.1016/j.rser.2011.11.035

2. A. Lewicki, J. Dach, P. Boniecki, W. Czekala, K. Witaszek, Advanced Materials Research, 909, 455$462 \quad$ (2014), $\quad$ DOI: 10.4028/www.scientific.net/AMR.909.455

3. D. Janczak, R. Mazur, P. Boniecki, J. Dach, J. Przybyl, P. Pawlak, K. Pilarski, W. Czekala, Proc. SPIE 8878: Fifth International Conference on Digital Image Processing (2013), DOI:10.1117/12.2031069

4. Budzianowski W.M., Renewable and Sustainable Energy Reviews, 16, 342-349 (2012), DOI: 10.1016/j.rser.2011.07.161

5. E. Wicher, K. Seifert, R. Zagrodnik, B. Pietrzyk, M. Laniecki, Journal of Hydrogen Energy, 38, 77677773 (2013), DOI: 10.1016/j.ijhydene.2013.04.008

6. M. Adamski, K. Pilarski, J. Dach, Journal of Research and Applications in Agricultural Engineering, 54, 3 (2009) 
7. A. Piwowar, M. Dzikuć, J. Adamczyk, Renewable and Sustainable Energy Reviews, 58, 69-74 (2016), DOI: $10.1016 /$ j.rser.2015.12.153

8. A. Lewicki, P.C. Rodriguez Carmona, J. Dach, P. Boniecki, D. Janczak, W. Czekala, M. Cieslik, J. Przybyl, Proceedings of the 2nd International Conference On Energy \& Environment: Bringing Together Engineering And Economics, 714-720 (2015), ISBN: 978-989-97050-4-3

9. R. Caceres, N. Coromina, K. Malińska, O. Marfa, Bioresource Technology, 179, 398-406 (2015), DOI: 10.1016/j.biortech.2014.12.051

10. J. Starzyk, W. Czekała, Archives of environmental protection, 40, 4, 125-135 (2014), DOI: 10.2478/aep-2014-0044

11. J. Dach, P. Boniecki, J. Przybył, D. Janczak, A. Lewicki, W. Czekała, K. Witaszek, P.C. Rodriguez Carmona, M. Cieślik, Energy, 69, 34-38 (2014) DOI: 10.1016/j.energy.2014.02.013

12. B. Igliński, A. Iglińska, W. Kujawski, R. Buczkowski, M. Cichosz, Renewable and Sustainable Energy Reviews, 15, 2999-3007 (2011), DOI: $10.1016 /$ j.rser.2011.02.037

13. Agricultural Agency Market http://www.arr.gov.pl/data/02004/rejestr_wytworco w_biogazu_rolniczego_17052017.pdf(accesed: 2017.05.17)

14. M. Zaborowicz, J. Przybył, K. Koszela, P. Boniecki, W. Mueller, B. Raba, A. Lewicki, K. Przybył, Proc SPIE. 9159: Sixth International Conference on Digital Image Processing (2014), DOI:10.1117/12.2064066

15. Q. Zhang, J. Hu, D.J. Lee, Renewable Energy, 98 (2016), DOI:10.1016/j.renene.2016.02.029

16. L. Appels, J. Baeyens, J. Degrève, R. Dewil, Prog Energy Combust Sci, 34, 755-781, (2008), DOI: 10.1016/j.pecs.2008.06.002

17. V.N. Gunaseelan, Biomass Bioenergy, 13, 83-114 (1997), DOI: 10.1016/S0961-9534(97)00020-2

18. J. Mata-Alvarez, S. Macé, P. Llabrés, Bioresource Technology, 74, 1, 3-16 (2000), DOI: 10.1016/S0960-8524(00)00023-7

19. J. Mata-Alvarez, J. Dosta, S. Macé, S. Astals, Crit Rev Biotechnol, 31, 99-111 (2011), DOI: 10.3109/07388551.2010.525496

20. A.J. Ward, P.J. Hobbs, P.J. Holliman, D.L. Jones, Bioresour Technol, 99, 7928-7940 (2008), DOI: 10.1016/j.biortech.2008.02.044

21. Y.Y. Choong, I. Norli, A.Z. Abdullah, M.F. Yhaya, Bioresource Technology, 209, 369-379 (2016), DOI: 10.1016/j.biortech.2016.03.028

22. C. Mao, Y. Feng, X. Wang, G. Ren, Renewable and Sustainable Energy Reviews, 45, 540-555 (2015), DOI: 10.1016/j.rser.2015.02.032

23. N. Nagao, N. Tajima, M. Kawai, C. Niwa, N. Kurosawa, T. Matsuyama, M.F. Yusoff, T. Toda,
Bioresour. Technol., 118, 210-218 (2012), DOI: 10.1016/j.biortech.2012.05.045

24. J. Lindmark, E. Thorin, R. BelFdhila, E. Dahlquist, Renewable and Sustainable Energy Reviews, 40, 1030-1047, (2014), DOI: 10.1016/j.rser.2014.07.182

25. P. Satjaritanun, Y. Khunatorn, N. Vorayos, S. Shimpalee, E. Bringley, Biomass and Bioenergy, 86, 53-64, DOI: 10.1016/j.biombioe.2016.01.018

26. M. Cieslik, J. Dach, A. Lewicki, A. Smurzynska, K. D. Janczak, J. Pawlicka-Kaczorowska, P. Boniecki, P. Cyplik, W. Czekała, K. Jóźwiakowski, Energy, 115, 1495-1502 (2016), DOI: 10.1016/j.energy.2016.06.070

27. M. Oslaj, B. Mursec, P.Vindis, Biomass and Bioenergy, 34, 11, 1538-1545 (2010), DOI: 10.1016/j.biombioe.2010.04.016

28. A. Wellinger, J. Murphu, D. Baxter, The biogas handbook. Sciance, production and applications (Woodhead Publishing Limited 2013), ISBN: 9780857097415

29. DIN 38 414, Bestimmung des Faulverhaltens "Schlamm und Sedimente" (BeuthVerlag GmbH, Berlin, 1985)

30. D. Deublein, A. Steinhauser, Biogas from waste and renewable resources (Wiley-VCH Verlag GmbH\& Co. KGaA, Weinheim, Germany 2008), ISBN: 9783-527-32798-0

31. T.J. Casey, Elsevier App. Sci. Pub.(90-103, London, 1986)

32. M. Kaltschmitt, H. Hartmann, EnergieausBiomasse - Grundlagen, Techniken und Verfahren (Springer Verlag Berlin, 2001), ISBN 978-3-540-85095-3

33. S.R. Lee, N.K. Cho, W.J. Maeng, J. Ferment. Bioengng., 80, 4, 415-417 (1995), DOI: 10.1016/0922-338X(95)94215-D

34. Niemiec M, Sikora J., Szeląg-Sikora A., Kuboń M., Olech E., Marczuk A. Przemysł chemiczny 96(3),685-688 (2017)

35. Niemiec M, Sikora J., Szeląg-Sikora A., Kuboń M., Olech E., Marczuk A. Przemysł chemiczny 96(11),1240-1243 (2017)

36. L.C. Smith, D.J. Elliot, A. James, Wat. Res., 30, 12 (1996), DOI: DOI: 10.1016/S0043-1354(96)001698

37. M. Maurer, J.P. Winkler, Biogas TheoretischeGrundlagen, Bau und Betrieb von Anlagen (VerlagC.F.Müller, Karlsruhe, 1980), DOI: 10.1002/star.19810331013 